\title{
The choice of the Southeast Asian market entry mode: A performance appraisal model based on fuzzy $\boldsymbol{A H P}$
}

\author{
Yu Fan \\ Experimental Management Center \\ Yunnan University of Finance and Economics \\ Kunming, China \\ bpippen@163.com
}

\author{
Yao Jianfeng \\ Experimental Management Center \\ Yunnan University of Finance and Economics \\ Kunming, China \\ yjf4311@hotmail.com
}

\begin{abstract}
Many studies have identified several factors that influence the choice of an entry mode for the Southeast Asian market. In this paper, a conceptual model of factors is proposed, research propositions are developed, and misty mathematics knowledge is used. We proposed a generalized model based on fuzzy AHP to evaluate the best entry mode dealing with the rating of both qualitative and quantitative criteria, in order to help managers make better decisions.
\end{abstract}

Keywords-Entry mode; Southeast Asian market; Fuzzy AHP

\section{INTRODUCTION}

As previously closed Southeast Asian markets open, and economies around Asia globalize, growth through the Southeast Asian market expansion has become an increasingly popular strategy. Spurred by technological advances in communications and transportation, Chinese firms are now finding it easier to expand internationally. However, Chinese firms interested in servicing the Southeast Asian market face a difficult decision with regards to entry mode selection, which has been a frontier issue in international marketing for several years. The entry mode is defined as an institutional arrangement that makes possible the entry of a company's products, human skills, management, technology, or other resources into another country. The four most common modes of the Southeast Asian market entry are sole venture, joint venture, licensing and exporting. Previous studies in the areas of industrial organization, international trade, and market imperfections have identified many factors that influence the choice of an entry mode for the Southeast Asian market.

\section{A. Internalization Theory}

Many studies investigated the transaction cost determinants of the Southeast Asian market entry mode choice. Transaction cost analysis has been extended by many researchers by integrating several factors into the given framework, such as cultural factors, environmental factors, network relationship and so on [1-3]. A major product-related factor influencing market entry strategies is the technological content of the product. A high technological content causes the firms to prefer modes of operation that involve complete control and ownership of their foreign affiliates. Host country's market size and market potential have also been found to be among the most important factors. In a large host market, companies will favor high-involvement entry modes, such as joint venture or sole ownership [4]. In a small market with low potential, the firms appear to favor entry modes that require low investment, such as licensing or exporting. However, this theory ignores some factors that play a major role in some settings, such as government restrictions and corporate strengths.

\section{B. Organizational Capabilities Theory}

The organizational capabilities theory is also among the most frequently applied perspectives, which regards a firm as a bundle of capabilities, where organization, technology and individual skill are linked together [5-6]. Entry mode decisions are made under the consideration related to the development of firm-specific resources and capabilities. Resource availability refers to the managerial and financial capacity of a firm for serving the Southeast Asian market. Firms that cannot shift their resources easily by transaction are more likely to choose a sole venture for entry. Firms without enough resources often favor joint venture to enhance their capabilities. However, it is difficult to measure the capabilities sometimes.

\section{The Eclectic Theory of International Production}

The eclectic framework introduced and developed by Dunning is a model commonly applied, which stipulated that the choice of an entry mode for a target market is influenced by three types of determinant factors: ownership advantages of a firm, location advantages of a market, and internalization advantages of integrating transactions within the firm [7][8][9]. The more advantages a firm has the greater the tendency of adopting the mode with a high level of control. Many empirical studies have attempted to use the framework in explaining choice between sole venture, joint venture, licensing and exporting, which have made substantial contributions to our understanding of the entry mode selection [10]. However, an important gap here is the issue of how the inter-relationships among the determinant factors influence firms' entry choices. The importance of examining the effects of inter-relationships derives from the fact that they may explain firm behaviors that cannot be captured by the independent effects of the factors. 


\section{Evolution Theory}

According to the evolution theory, a firm's entry mode develops with its multinational experience increases. Firms without the Southeast Asian market experience are likely to have greater problems in managing the operations. They have been observed to understate the potential returns while overstating the potential risks, which makes choice of noninvestment modes more probable for them [11]. Conversely, firms with higher multinational experience may be expected to prefer investment modes of entry. Considering multinational experience as the only variable in entry mode choice, this theory make the problem over simplification.

In view of the deficiency of the existing theories, we should do the research in the following aspects: 1) redefining the conceptual frameworks with clear hypothesis and strict deduction, 2) considering the political stability and economic infrastructure of a host country, 3) making full use of modern economic analysis tools.

\section{APERFORMANCE APPRAISAL OF THE SOUTHEAST ASIAN MARKET ENTRY MODE}

As we know, entry modes differ greatly in their mix of advantages and drawbacks. The usual methods of performance appraisal, such as production function, utility function, and techno-economic indicators, are not applicable for such a complex system. Analytic Hierarchy Process (AHP) is a multicriteria decision making tool for dealing with complex, unstructured and multi-attributed problems. The most creative part of decision-making is modeling the problem. Identification of the decision hierarchy is the key factor in using AHP. Figure 1 presents a model of entry mode choice that extends extant theory, concerning the following question: under what circumstances is an entry mode the most efficient choice for the Southeast Asian market.

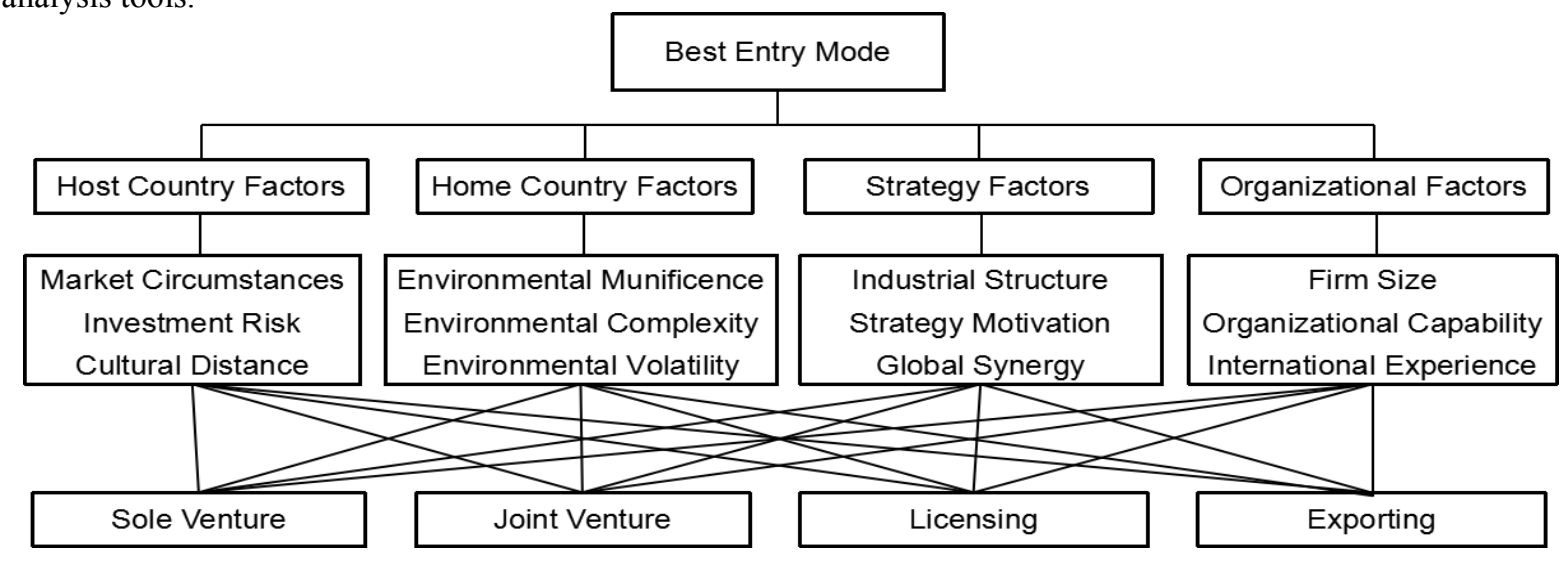

Fig. 1. A Model of the Southeast Asian Market Entry Mode Selection

In Fig. 1, market circumstances refers to host country's market size and market structure. Investment risk refers to host country's political and economic stability and its policies and regulations. Cultural distance encompasses differences in language, ideology, work ethic, social structure and so on between the host country and the home country. Environmental munificence refers to the relative abundance of resources in domestic environment and the capacity to support growth. Environmental complexity refers to the concentration and heterogeneity of environmental elements. Environmental volatility is defined as the level of instability or turbulence facing a domestic environment and reflects change that is difficult to predict. Industrial structure refers to the intensity of competition in a market and the industrial concentration. Strategy motivation determine the required level of control to achieve a firm's objectives in the foreign market. Global synergy refers to foreign affiliates around the world draw upon the experience and knowledge of the parent firm for servicing the market in the host country. Firm size refers to its total assets, substantial financial, human resources and so on. Organizational capabilities are firm specific, and they reflect a firm's competitive advantages. International experience often reflected in the ratio of foreign sales to total sales, number of foreign markets currently served, and knowledge of the host country.

\section{OUtLINE OF THE EVALUATION APPROACH BASED ON FUZZY AHP}

AHP is useful for selecting the best among alternatives based on certain criteria. It has been extensively applied by professionals and academics, mainly in applications involving financial decisions associated to non-financial attributes. However, the conventional AHP cannot reflect some difficultto-measure variables yet [12]. Fuzzy AHP, in which all calculations are carried out by fuzzy numbers, was developed to solve the hierarchical fuzzy problems. In this paper, Fuzzy AHP method is suggested to solve entry mode selection problem using multi-criteria decision-making process. The outlines of the analysis method are given in the following.

\section{Step 1: Hierarchical structure construction.}

The first step of Fuzzy AHP consists of developing a hierarchical structure of the assessment problem. We have devised a hierarchical model (Fig. 1). The first level of the model is objective, which is the determination of the most eligible entry mode for the Southeast Asian market in this study. The objective is divided into four main criteria, which are A: host country factors, B: home country factors, C: strategy factors and D: organizational factors. Each criterion is divided into 3 sub-criteria, which are $A_{1}$ : market circumstances, $\mathrm{A}_{2}$ : investment risk, $\mathrm{A}_{3}$ : cultural distance, $\mathrm{B}_{1}$ : environmental 
munificence, $\mathrm{B}_{2}$ : environmental complexity, $\mathrm{B}_{3}$ : environmental volatility, $\mathrm{C}_{1}$ : industrial structure, $\mathrm{C}_{2}$ : strategy motivation, $\mathrm{C}_{3}$ : global synergy, $\mathrm{D}_{1}$ : firm size, $\mathrm{D}_{2}$ : organizational capability, $\mathrm{D}_{3}$ : international experience. The last level of the model includes alternatives, which are some common modes of the Southeast Asian market entry.

Step 2: Constructing the fuzzy judgment matrix.

It is necessary to construct pairwise comparison matrix among all the criteria in the dimensions of the hierarchy system, by asking the experts which one of two criteria is more important.

Triangular fuzzy numbers are used to indicate the relative importance of each pair of elements here [13]. For example, $\widetilde{A}$ is a fuzzy number, and $\widetilde{A}=(l, m, u)$ means:

$$
\mu \widetilde{A}(x)=\left\{\begin{array}{l}
\frac{x-l}{m-l}, l \leq x \leq m, \\
\frac{u-x}{u-m}, m \leq x \leq u, \\
0, \quad \text { otherwise },
\end{array}\right.
$$

where $\mu \widetilde{A}(x)$ is the membership function of $\widetilde{A}$.

The experts should use the linguistic scales to assign the pairwise comparisons and then convert the linguistic variables to fuzzy numbers using Table 1 [14].

TABLE I. MEMBERSHIP FUNCTION OF LINGUISTIC SCALE

\begin{tabular}{|c|c|c|}
\hline Fuzzy number & Linguistic scales & Membership function \\
\hline$\widetilde{1}$ & Equally important & $(1,1,3)$ \\
\hline$\widetilde{3}$ & Weakly important & $(1,3,5)$ \\
\hline$\widetilde{5}$ & Essentially important & $(3,5,7)$ \\
\hline$\widetilde{7}$ & Very strong important & $(5,7,9)$ \\
\hline$\widetilde{9}$ & Absolutely important & $(7,9,9)$ \\
\hline
\end{tabular}

The fuzzy comparison value of criterion $\mathrm{i}$ to criterion $\mathrm{j}$ is denoted as $\widetilde{c}_{i j}$, and the fuzzy judgment matrix $\widetilde{C}$ is constructed as follows:

$$
\widetilde{C}=\left[\begin{array}{cccc}
\tilde{1}_{1} & \widetilde{c}_{12} & \ldots & \widetilde{c}_{1 n} \\
\widetilde{c}_{21} & \widetilde{1} & \ldots & \widetilde{c}_{2 n} \\
\ldots & \ldots & \ldots & \ldots \\
\widetilde{c}_{n 1} & \widetilde{c}_{n 2} & \ldots & \widetilde{1}
\end{array}\right]
$$

where

$$
\widetilde{c}_{i j}=\left\{\begin{array}{c}
\tilde{1}, \tilde{3}, \widetilde{5}, \widetilde{7}, \widetilde{9}, \quad i \text { is more important than } j, \\
\tilde{1}, \quad i=j, \\
\tilde{1}^{-1}, \widetilde{3}^{-1}, \widetilde{5}^{-1}, \widetilde{7}^{-1}, \widetilde{9}^{-1}, \quad i \text { is less important than } j
\end{array}\right.
$$

Step 3: Calculating the relative weights of each criterion.
The relative weights of each criterion are calculated as follows [15]:

$$
\begin{aligned}
& \widetilde{r}_{i}=\left[\widetilde{c}_{i 1} \otimes \widetilde{c}_{i 2} \otimes \cdots \otimes \widetilde{c}_{i n}\right]^{\frac{1}{n}}, i=1,2, \cdots, n,
\end{aligned}
$$

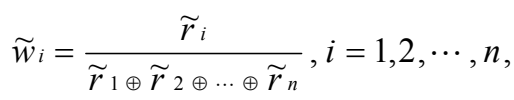

where $\widetilde{r}_{i}$ is the geometric mean of fuzzy comparison value of criterion $i$ to each criterion, and $\widetilde{w}_{i}$ is the fuzzy weight of criterion $\mathrm{i}$.

Step 4: Calculating the priority weight of each alternative

The final priority weight value of each alternative is calculated as follows:

$$
\widetilde{V}_{k}=\sum_{i=1}^{n} \widetilde{w}_{i} \cdot \widetilde{r}_{i k},
$$

where $\widetilde{V}_{k}$ is the final weight value of alternative $\mathrm{k}$, and $\widetilde{r}_{i k}$ is the fuzzy weight of criterion i to alternative $\mathrm{k}$.

Step 5: Choosing the best alternative.

The final weights of all the alternatives, which are indicated by triangular fuzzy numbers, can be defuzzified and ranked by the fuzzy means of them [16]. If $\widetilde{A}=(l, m, u)$, then its fuzzy mean $x(\tilde{A})$ is calculated as follows:

$$
x(\tilde{A})=\frac{l+m+u}{3} .
$$

The performance of the alternatives with respect to the objective can be ranked by the fuzzy means of their final weights. The kth mode should be chosen when $x\left(\widetilde{V}_{k}\right)$ is the maximum value.

\section{CONCLUSION}

One of the most critical decisions faced by Chinese firms seeking to enter the Southeast Asian market is the choice of entry mode. Given certain characteristics of the product, the firm and the environment, decision makers should choose the most efficient entry mode from sole venture, joint venture, licensing and exporting. These modes have great differences in their mix of advantages and drawbacks, which are difficult to evaluate.

This study has made an attempt to investigate factors that are important in Chinese firms' choice of entry mode for the Southeast Asian market. Several factors that determine the choice have been identified in previous theories and studies. We proposed a performance appraisal model involving 12 important factors, which can be classified into four categories: host country factors, home country factors, strategy factors and organizational factors. The relative weights of these factors cannot be given previously, because different factors play a major role in different settings, some of which are in conflict. Managers are required to weigh these factors before the decision of the entry mode selection every time. 
Decision makers face rising and complex environments today, and they are often uncertain in assigning the evaluation scores in crisp value. Therefore, we tried to design a multicriteria decision-making model based on fuzzy set theory. The outlines of the analysis method based on fuzzy AHP have been given and managers can take it step by step to select the best alternative entry mode. In the future research, we may try to simplify the proposed method, and reduce the calculation work.

\section{ACKNOWLEDGMENT}

The authors would like to thank Professor Liu and Professor Wang, for their constructive comments and valuable guidance that led to an improved version of this paper.

\section{REFERENCES}

[1] J.F. Hennart, "The Transaction Costs Theory of Joint Ventures: An Empirical Study of Japanese Subsidiaries in the United States," Management Science, vol. 37, 1991, pp. 483-497.

[2] N. Coviello, and H. Munro, "Network relationships and the internationalisation process of small software firms," International Business Review, vol. 6, 1997, pp. 361-386.

[3] D. Yiu, and S. Makino, "The Choice Between Joint Venture and Wholly Owned Subsidiary: An Institutional Perspective," Organization Science, vol. 13, 2002, pp. 667-683.

[4] M.K. Erramilli, "Nationality and Subsidiary Ownership Patterns in Multinational Corporations," Journal of International Business Studies, vol. 27, 1996, pp. 225-248.
[5] P.S. Aulakh, and M. Kotabe, "Antecedents and Performance Implications of Channel Integration in Foreign Markets," Journal of International Business Studies, vol. 28, 1997, pp. 145-175.

[6] A. Madhok, "The nature of multinational firm boundaries: Transaction costs, firm capabilities and foreign market entry mode," International Business Review, vol. 7, 1998, pp. 259-290.

[7] J.H. Dunning, "Toward an eclectic theory of international production," The Eclectic Paradigm. Palgrave Macmillan. UK, 1980, pp. 9-31.

[8] J.H. Dunning, "The theory of international production," International Trade Journal, vol. 3, 1988, pp. 21-66.

[9] J.H. Dunning, "The Eclectic Paradigm of International Production: A Restatement and Some Possible Extensions," Journal of International Business Studies, vol. 19, 2015, pp. 1-31.

[10] B. Kogut, and H. Singh, "The Effect of National Culture on the Choice of Entry Mode," Journal of International Business Studies, vol. 19, 1988, pp. 411-432.

[11] K.D. Brouthers, and J.F. Hennart, "Boundaries of the Firm: Insights From International Entry Mode Research," Journal of Management, vol. 33, 2007, pp. 395-425.

[12] O.S. Vaidya, and S. Kumar, "Analytic hierarchy process: An overview of applications," European Journal of Operational Research, vol. 169, 2006, pp. 1-29.

[13] Laarhoven, P.J.M. Van, and W. Pedrycz, "A fuzzy extension of Saaty's priority theory," Fuzzy Sets \& Systems, vol. 11, 1983, pp. 199-227.

[14] F. Chiclana, F. Herrera, and E. Herrera-Viedma, "Integrating three representation models in fuzzy multipurpose decision making based on fuzzy preference relations," Fuzzy Sets \& Systems, vol. 97, 1998, pp. 33-48.

[15] J.J. Buckley, "Fuzzy hierarchical analysis," Fuzzy Sets \& Systems, vol. 17, 1985, pp. 233-247.

[16] E.S. Lee, and R.J. Li, "Comparison of fuzzy numbers based on the probability measure of fuzzy events," Computers \& Mathematics with Applications, vol. 15, 1988, pp. 887-896. 